\title{
PASZKWIL MNICHA MAKSENCJUSZA NA PAPIEŻA HORMIZDASA JAKO PRZYKLAD INWEKTYWY CHRZEŚCIJAŃSKIEJ
}

Wystąpienie mnicha Maksencjusza przeciw papieżowi Hormizdasowi należy wpisać w trwający kilka wieków spór o uznanie uchwał Soboru Chalcedonskiego w całym Kościele, a mówiąc bardziej szczegółowo, w poczynania Stolicy Apostolskiej, patriarchów Konstantynopola i władców Bizancjum, zmierzające do przezwyciężenia monofizytyzmu ${ }^{1}$. Srodowisko jego zwolenników, działające głównie w Egipcie, Syrii i krainach z nimi związanych, było bardziej aktywne we wszelkich poczynaniach. Przykładem był Piotr Folusznik, monofizycki patriarcha Antiochii, który do Trishagionu (,Swięty Boże, Swięty mocny, Swięty a nieśmiertelny”) dodał: „któryś dla nas został ukrzyżowany” (qui passus es pro nobis). Formuła ta nie byla niepoprawną, ale bez dodania wyrażenia: „w ciele", dla katolików była nie do przyjęcia. Wyrażenie to zaczęli dodawać zwolennicy Soboru Chalcedońskiego, określani w literaturze naukowej neochalcedończykami, uznając, że w ten sposób da się pogodzić katolików z monofizytami. Zaproponowali oni nową formułę teopasyjną, której zasadniczą tezą było głoszenie, że Jeden z Trójcy Świętej cierpiał za nas w ciele (Unus de Trinitate passus est in carne $)^{2}$. Glównymi propagatorami neochalcedonizmu byli związani ze środowiskiem mnichów scytyjskich: Efrem z Antiochii, Teodor z Raithu, Jan Scholastyk, Leoncjusz z Jerozolimy i nasz główny bohater Jan Maksencjusz. Ich doktryna polegająca na unikaniu drażliwych kwestii dzielących obie strony, a akcentowaniu punktów wspólnych, święciła triumf na Soborze w Konstantynopolu w 553 roku. W gruncie rzeczy jednak oznaczała odejście od chrystologii zawartej w Tomusie papieża Leona Wielkiego. Mnisi, z których opinią musiało się liczyć wielu biskupów, głosili swoją tezę najpierw w prowincji Scythia Minor, której biskup Paternus popadł z nimi w konflikt, gdyż nie akceptował ich nauczania. Przybyli więc na początku 519 roku do stolicy Bizan-

${ }^{1}$ Por. B. Altaner, Zum Schriften der „skythischen” (gotischen) Mönche, w: Kleine patristische Schriften, TU 83, Berlin 1967, 489-506.

${ }^{2}$ Formuły takiej użyl już w V wieku patriarcha Konstantynopola Proklus, por. L. Duchesne, L'Église au VI' siècle, Paris 1925, 56. 
cjum, gdzie zostali potraktowani z powagą z tej racji, że jeden z nich, Leoncjusz, podawał się za krewnego ważnej osobistości na dworze cesarza Justyna, jaką był Witalian, pełniący wespół z Justynianem urząd konsula. Konflikt rozszerzył się z chwilą, gdy mnisi scytyjscy zaczęli twierdzić, że przywrócenie jedności kościelnej na gruncie Chalcedonu nie wystarczy, gdyż za osłoną jego uchwał mogą kryć się zwolennicy Nestoriusza ${ }^{3}$. Wobec tego konieczną rzeczą jest używanie proponowanej przez nich nowej formuly teopasyjnej. Z kolei akojmeci, którzy jak mało kto byli wypróbowanymi obrońcami czystości wiary, zarzucili teopaschistom monofizytyzm ${ }^{4}$. Akurat $w$ momencie tych gorących sporów przybyła do Konstantynopola legacja Stolicy Apostolskiej w osobach biskupów Jana i Germanusa z Kaprii, kapłana Blandusa, diakona Feliksa i notariusza Piotra. Towarzyszył jej też diakon Dioskur, doskonale znający język grecki i bizantyjskie zwyczaje. Legaci mieli za zadanie przywrócenie jedności w Kościele, która w wyniku schizmy akacjańskiej kładła się cieniem na wzajemnych relacjach między Rzymem a Konstantynopolem; istotnie przywrócenie upragnionej jedności nastąpiło w Wielkim Tygodniu 519 roku $^{5}$.

Korzystając z obecności papieskiej legacji, dyskutujące strony zwróciły się do niej o rozstrzygnięcie sporu. Odbyła się raz jeszcze dyskusja w obecności legatów i biskupa Konstantynopola Jana. Niejaki diakon Wiktor, któremu neochalcedończycy zarzucali nestorianizm, opowiedział się za uchwałami Chalcedonu bez żadnych uzupełnień, mnisi scytyjscy zaś obstawali przy swojej formule o jednym $z$ Trójcy ukrzyżowanym. Papiescy wysłannicy okazali się dobrymi dyplomatami. Zasłaniając się brakiem jakichkolwiek instrukcji do rozstrzygania sporu, przedstawili papieską formułę wiary (libellus) jako rozwiązanie konfliktu. Należało zatem przyjąć Chalcedon i podpisać papieską formułę wiary; wszelkie dodatki uznali za zbędne. Odbyło się jeszcze kilka dyskusji, które nakazał sam cesarz Justyn w celu pogodzenia mnichów z biskupem Paternusem. Gdy one nie przyniosły żadnego rezultatu, cesarz polecil przeprosić mnichom biskupa i dojść z nim do porozumienia ${ }^{6}$. Rozczarowani taką decyzją mnisi postanowili udać się do Rzymu, by swoje poglądy przedstawić papieżowi Hormizdasowi. W ślad za nimi poszły dwa listy, jeden od legacji papieskiej, drugi od diakona Dioskura, w których nadawcy przekazując swoje odczucia odnośnie do zaistniałego problemu, ostrzegali papieża, by był bardzo ostrożny w podjęciu mnichów i nie akceptował ich poglądów, gdyż to mogłoby zepsuć proces przywracania jedności w Kościele w oparciu o Chalcedon, list Leona Wielkiego i papieską formułę wiary.

${ }^{3}$ Por. P.T.R. Gray, The defence of Chalcedon in the East (451-553), Leiden 1979, 49.

4 Por. W. Haacke, Die Glaubensformel des Papstes Hormisdas im Acacianischen Schizma, Roma 1939, 88.

5 Por. S. Koczwara, Wokót sprawy Akacjusza, Lublin 2000, 159-181.

6 Por. Suggestio Germani et Joannis episcoporum (Collectio Avellana 217), CSEL 35/2, 677 679. 


\section{Oto fragment $\mathrm{z}$ listu legatów:}

„piszemy to, co uważamy za słuszne, a w waszej mocy, Ojcze Święty, leży przyjęcie tego, co nakazuje Bóg. Mnisi dla własnej satysfakcji usiłują uzyskać to, byśmy wyznawali, że jeden z Trójcy cierpiał, czego przecież nie twierdzili ani Ojcowie, ani Sobory [...]. Dlatego upraszamy, aby papież ze zwykłą dla siebie ostrożnością i przezornością pomyślał, jak przyjąć tych, którzy odeszli od nas i zostali wyłączeni z naszej wspólnoty; jak należy im odpowiedzieć i w jaki sposób odrzucić ich artykuły, bo przecież wzdraga się przed nimi wszystkimi Kościół w Konstantynopolu"7.

Znacznie ostrzej pisał do papieża Justynian, którego zdaniem ich podróż do Rzymu miała na celu szerzenie niezgody w Kościele. Papież zatem winien ich jak najszybciej oddalić:

„Stwierdziliśmy - pisze Justynian - że są pewni mnisi, którym bardziej się podoba niezgoda niż miłość i pokój Boży [...]. Imiona tychże burzycieli to: Achilles, Jan, Leoncjusz i Maurycy. Tych to Wasza Miłość - rozpoznając trafnie ich zawiść zechce odpowiednio potraktować i oddalić, gdyż przez swoje brednie pragną wprowadzić nowości do Kościoła".

Po takich ostrzeżeniach nie należy się dziwić, że przyjęcie mnichów w Rzymie było bardzo chłodne. Gdy papież przewlekał całą sprawę i nie dawał na listy odpowiedzi, niespodziewanie dotarł do niego drugi list Justyniana. Hormizdas mógł się czuć zaskoczonym, gdyż treść listu była całkowicie inna od poprzedniego. Justynian prosi w nim papieża, by dał jak najszybszą odpowiedź na postulaty mnichów i to taką, która by ich usatysfakcjonowała. Co kryło się za zmianą postawy Justyniana? Na pewno nie bez znaczenia było to, ze mnichów popierał Witalian, który mógł przekonać Justyniana, by uczynił podobnie, ale najistotniejsze było to, że przyszły cesarz, będący wytrawnym teologiem, doszedł do wniosku, że formuła używana przez teopaschistów, mogłaby zapewnić pokój religijny a poniekąd i polityczny w imperium'.

${ }^{7}$ Tamż 10-12, CSEL 35/2, 679: „Nobis quod visum est, scripsimus; in vestra potestate est deliberare, quod vobis Deus imperaverit, quoniam hoc illi nituntur assere eo modo sibi satisfacere cupientes, ut ita profiteamur et dicamus unum de Trinitate passum esse, quod nec Patres nec synodi dixerunt [...]. Quapropter rogamus, ut consueta cautela et qua solet domnus noster vigilantia cogitetis, et quomodo suscipiendi sint, qui a nobis taliter recesserunt et nostra fuerunt communione seiuncti, et quid eis respondeatur vel quomodo eorum capitula repellantur, quia eos omnes Constantinopolitana catholica exhorret Ecclesia".

${ }^{8}$ Epistola Justiniani (Collectio Avellana 187), CSEL 35/2, 644: „Sed quoniam comperimus quosdam nomine monachos, quibus magis misericordia studio est et quam caritas et pax Dei [...]. Sunt autem nomina eorum Achilles, Johannes, Leontius et Mauritius [...]. Quos beatitudo vestra praesentibus scriptis causam livoris eorum cognoscens ita, ut merentur, suscipere et a se longe pellere dignetur, quoniam vaniloquia ipsorum festinantium novitiates introducere in Ecclesia".

9 Por. Duchesne, dz, cyt., s. 58; A.A. Vasiliev, Justin the First. An introduction to the epoch of Justinian the Great, Dumbarton Oaks Studies 1, Cambridge Mass. 1950, 193; Gray, dz. cyt., s. 49-50. 
Tymczasem mnisi, którzy na dobre zadomowili się w Rzymie, zaczęli propagować swoje tezy wśród ludu rzymskiego, a nawet w senacie. Papież zaś Hormizdas nie tylko, że musiał wysłuchać ich oskarżeń, dotyczących diakona Wiktora, który z nimi polemizował w Konstantynopolu, ale także tych, w których zaatakowali oni legatów papieskich, dających jakoby posłuch Wiktorowi. Jak przystało na prawdziwego pasterza, papież wysłuchał ich racji i dla lepszego poznania sprawy kazał im pozostać w Rzymie, aż do powrotu legacji. Pisał o tym wszystkim Justynianowi, prosząc jednocześnie, by diakon Wiktor przybył do Rzymu w celu wyjaśnienia konfliktu $z$ mnichami ${ }^{10}$. Tym było to na rękę. Tak zadomowili się w środowisku kolonii greckiej z ośrodkiem przy Santa Maria in Cosmedin, że ani myśleli opuszczać Rzymu, choć bardzo nalegał na to Justynian w kolejnym swoim liście z 15 X 519 r., jak i sam papież. Hormizdas bowiem zaczął skłaniać się ku pomysłowi, by sprawę oddać do rozstrzygnięcia patriarsze Janowi ${ }^{11}$.

Do papieża napisał też list diakon Dioskur, który raz jeszcze zreferował to, co wydarzyło się w Konstantynopolu, a w zakończeniu listu dał opinię o przywódcach scytyjskich mnichów Achillesie i Maksencjuszu:
„Zaś Maksencjusz, który mieniąc się opatem twierdzi, że utworzył społeczność mniszą, jeśli go zapytać, $\mathrm{z}$ jakimi mnichami żyl, w jakim klasztorze, pod jakim opatem stal się mnichem, nie potrafi powiedzieć. To samo powiedziałbym, gdy chodzi o Achillesa, lecz uważam to za zbędne. Wystarczy rzec tylko to, że zawsze zachowuje tajemnicę, bo ma takie sumienie, które potępią wszyscy katolicy"12.

Tymczasem w Rzymie udało się mnichom nakłonić swego rodaka Dionizego Małego, który zasłynął z obliczenia początku ery chrześcijańskiej, by stanął po ich stronie. Nawiązali też więź z biskupami z Afryki, którzy byli wygnani $z$ kraju przez króla Trazamunda ${ }^{13}$. Swoją doktrynę propagowali intensywnie i hałaśliwie, ale papieżem był Hormizdas, Pers z pochodzenia, który jak mało kto znał wszystkie wschodnie sztuczki, będące jakąś tam z kolei mutacją fides graeca. Podjął decyzję, by usunąć mnichów z Wiecznego Miasta, a w liście do wpływowego na dworze cesarskim biskupa Possesora wyłuszczył swoje racje, stojące za tą decyzją. Warto tu przytoczyć dużą część tego listu,

${ }^{10}$ Por. Epistola Hormisdae ad Justinianum (Collectio Avellana 189), CSEL 35/2, 646-647.

11 Por. Suggestio Dioscori diaconi 1 (Collectio Avellana 224), CSEL 35/2, 685: „Per Eulogium v. c. litteras beatitudinis vestrae suscepimus, in quibus significastis intentionem monachorum Scythicorum et quomodo visum fuerat apostolatui vestro episcopo Constantinopolitano causam delegare, ut ipse inter eos et qui ab eis impetuntur audiret".

12 Tamże 11, CSEL 35/2, 687: „Maxentius tamen quod sub abbatis vocabulo dixit se congregationem habere, si interrogetur aut cum quibus manachis vixit aut in quo manasterio aut sub quo abate monachus factus est, dicere non potest. Similiter et si de Achille dicere voluero. Rem facio supervacuam; cui hoc sufficit: semper latere propter conscientiam suam ab omnibus catholicis damnatam".

13 Por. Duchesne, dz. cyt., s. 62; Vasiliev, dz. cyt., s. 194. 
gdyż stanowi on bezpośrednią przyczynę paszkwilu - odpowiedzi mnicha Maksencjusza:

„Dobrze wie Kościól Boży o burzach i złej pogodzie w jego łonie i chociaż trwa niewzruszenie przy sterze swej wladzy, ciągle nękany jest napadami wzburzonych fal [...]. Lecz mimo to, należy nam kroczyć śladami tego, co pewne [...]. Kto nie jest atakowany, nie idzie naprzód. Któż jest wolny od żądła pokusy? Prawie przez cały rok mamy doświadczenia z pewnymi Scytami [...]. Znosiliśmy ich cierpliwie, spodziewają się, że lagodnością uleczymy ich od ran wewnętrznych, tolerując ich subtelną chytrość budowania krętactwa i pod pozorem pobożności siejących pełne nienawiści zatrute nauki [...]. Nigdy nie ma u nich owej, nakazanej w Nowym Prawie miłości. Zamiast myśleć o pokoju zostawionym nam przez Pana przy Jego odejściu, zależy im opornym, aby nie ustępować, a tylko narzucać swoje poglądy. Gardzą autorytetem Ojców, zawsze są żądni nowinek, zawsze uważają za prawdziwą jakąkolwiek latwo wymyśloną sentencję. Tak wzrośli w dumę, tak urosła ich pycha, iż sądzą, że do ich poglądów powinny przychylić się oba Kościoły (wschodni i zachodni). Nie dopuszczają do tego, by do wiernych zaliczać trzymających się niezmiennie Tradycji, gdy widzą, że nie chcą się nagiąć do ich poglądów. Biegli w tym, by zasiewać zło, by fabrykować truciznę zawiści i uwłaczać innym; nienawidząc niewzruszone ciało Kościoła wzniecają bunty i zawiści, a zamiast posłuszeństwa, które w klasztorach jest najważniejszym nakazem dyscypliny, ponad nią usilnie trwają w opornej pysze. Nie jesteśmy w stanie ułagodzić ich ani upomnieniem, ani łagodnością, ni swoim autorytetem. Publicznie występują na zebraniach, zakłócając spokój różnych społeczności, powołując się nawet na powagę królów. I gdyby nie przeciwstawiła się im stałość we wierze wiernego ludu, skłóciliby go, zasiewając ziarna diabelskiego kąkolu nieporozumień i niezgody. Jednakże z pomocą Bożą wykorzeniono $\mathrm{z}$ ich środowisk niezgodę. Teraz zaś dochodzimy do przekonania o prawdziwości przepowiedni apostolskiej, że w ostatecznych dniach nastaną trudne czasy, a ludzie będą miłować tylko siebie, na zewnątrz zachowując pobożność, a faktycznie postawą swoją zaprzeczając cnotom. Należy ich zatem unikać! Uważamy za potrzebne, by przy okazji oznajmić to wszystko Twojej Miłości, abyście nie pozostawali w niewiedzy, a gdy ich błędy tam dotrą, wiedzieli, jak oni się zachowywali w Rzymie, by oszustwami i was nie podeszli" ${ }^{14}$.

${ }^{14}$ Epistola Hormisdae ad Possessorem episcopum 3-10 (Collectio Avellana 231), CSEL 35/2, 697-699, lub PG 86, 91-94: „Sed non est ignota ecclesiis Dei de huiusmodi procellis aut insueta tempestas: quamvis rectoris sui gubernaculo inconcussa persistat, variis tamen insurgentium fluctuum laborat vexata turbinibus. [...]. Nos fixis decet instare vestigiis [...]. Qui cum impellitur non movetur. Ubi non variae temptationis aculei? Quales per hunc fere iugem annum quorundam Scytharum., qui monachos praeferebant specie non veritate, professione non opere, subtili tectas calliditate versutias et sub religionis obtentu famulantia odiis suis venena pertulimus studentes eos ab interno vulnere medicabilis patientiae moderamine sanare, beati Pauli monita non tacentes [...]. Numquam apud eos caritas novo commendata praecepto. Numquam pax dominico relicta discessu: una pertinacis cura propositi rationi velle imperare, non cedere: contemptores auctoritatum veterum, novarum cupidi quaestionum; solam putantes scientiae rectam viam qualibet conceptam facilitate sententiam: eo usque tumoris elati. Ut ad arbitrium suum utriusque orbis putent inclinandum esse iudicium, nec in numero fidelium deputantes sequaces traditionis paternae, si suae viderint cedere nolle sententiae; docti crimina serere, obtrectationum venena componere. Inte- 
Mnisi wrócili do Konstantynopola skarżąc się swojemu przełożonemu, jakie ich to spotkały szykany w Rzymie ze strony papieża. Nie omieszkali, oczywiście, podać swojej wersji wydarzeń twierdząc, że wypędzono ich dlatego, by oszczędzić papieskim legatom przykrej konfrontacji po ich powrocie do Rzymu.

Tymczasem biskup Possesor mając w ręku list papieski nie odmówił sobie przyjemności nakreślenia odpowiedniego portretu mnichów nad Bosforem. Jan Maksencjusz poczuł się zatem zobowiązany, by dać odpowiedź na ten list. I trzeba przyznać, że zrobił to sprytnie. Najpierw poddał w wątpliwość autentyczność listu biskupa Rzymu rozpowszechnionego przez Possesora, a potem przystąpił do rozprawy $z$ autorem, starając się zbić punkt po punkcie papieskie stwierdzenia tak sprytnie, że na każdy zarzut odpowiadał zarzutem. Innymi słowy stając w szranki z papieżem wykazał, że zna podstawową regułę walki głoszącą, iż najlepszą obroną jest atak. Ale myliłby się ten, kto istotę sprawy upatrywałby tylko w epitetach i zarzutach stawianych Hormizdasowi. Raz po raz przewija się w nich naczelna teza teopasyjna o jednym z Trójcy ukrzyżowanym za nas. To ten list Maksencjusza, będący odpowiedzią papieżowi, jest owym paszkwilem, który omówimy poniżej ${ }^{15}$. Liczy on kilkadziesiąt stron i składa się jakby $\mathrm{z}$ dwóch części: pierwsza poświęcona jest polemice $\mathrm{z}$ papieżem Hormizdasem, a $\mathrm{w}$ istocie propaguje doktrynę neochalcedońską, druga poświęcona została obalaniu twierdzeń biskupa Fausta z Galii, na którym ciążył zarzut semipelagianizmu; my zajmiemy się tylko częścią pierwszą ${ }^{16}$.

Na samym początku Maksencjusz bardzo umiejętnie naprowadza swoją replikę na tory, które sobie wyznaczył, czyli że to on kroczy drogą prawdy, a przeciwnik, który pozostaje w ukryciu, drogą fałszu, pisząc:

„ponieważ falsz nie ma odwagi z otwartym czołem występować przeciwko prawdzie, by nie być powalonym na ziemię bardzo mocnymi argumentami, to walczy pod pozorem jej cienia"17.

grum ecclesie corpus odisse, seditiones instruere. Invidiam concitare et pro oboedientia, quae in cenobiis principatum regularis obtinet disciplinae, obstinationem pertinacis amare superbiae. Non illos potuimus monitis, non mansuetudine, non auctoritate comprimere. In publicum usque prodiere conventum ad concussionem quietis circa regum etiam statuas inclamantes. Et nisi fidelis populi constantia restitisset, per diabolicae semina nefanda zizaniae apud illos dissensionem et discordiam commonissent. Per quos adiutorio Dei de regionibus eorum est pulsa dissensio. Sero probavimus prophetica apostolum voce dixisse in novissimis diebus instare tempora periculosa et fore homines sui tantum amatores, habentes formam pietatis, virtutem autem eius abnegantes, itaque esse vitandos. Haec ideo dilectioni vestrae indicanda sub occassione credidimus, ne, si illuc fuerint forte delati, ignorantes, quemadmodum se in Romana urbe tractaverint, sub aliqua verborum simulatione deciperent".

15 Por. Joannis Maxentii ad epistolam Hormisdae Responsio, PG 86, 93-112.

16 Warto przytoczyć w tym miejscu zdanie Baroniusza, który ostrzega, że „dzielo Maksencjusza należy czytać $\mathrm{z}$ największą ostrożnością i nie należy mu ufać, ponieważ może kryć w sobie truciznę eutychiańskiej herezji", por. C. Baronius, Annales ecclesiastici a Christo nato ad annum 1198, VII, Lucca 1738-1753, cap. 105: annus 519; zob. też PG 86, 76.

17 Joannis Maxentii ad epistolam Hormisdae Responsio, PG 86, 93C: „Et quia aperta fronte 


\title{
By móc nazwać papieża heretykiem, wysunął Maksencjusz wątpliwość, czy autorem rozpowszechnionego przez Possesora listu jest sam papiez:
}

\begin{abstract}
„Ponieważ rozpowszechnia się przez wrogów pewien list, wydany jakoby przez biskupa Rzymu, w którym to liście znajdują się niesłuszne zarzuty wobec scytyjskich mnichów [...] rozważmy, czy został on ułożony przez pasterza Kościoła, czy raczej przez nieprzyjaciół. Waham się, jak ma być przyjęty ów kapłański list, skoro nie promieniuje żadnym światłem prawdy ani nie zawiera w sobie nic z pasterskiego nauczania [...]. Natomiast wydaje się być pełen pustych pomówień, jakie zwykle pochodzą z zazdrości kłótliwego charakteru [...]. Może więc został on, co uważam za bardziej wiarygodne, napisany przez heretyków, którzy dla wzburzenia umysłów wiernych i dla wzniecenia nienawiści do biskupa Rzymu, rozpowszechniają wszędzie ten list wlaśnie pod jego imieniem, chcąc utrzymać wieczną nienawiść między Kościołami [...]. A zatem autor tego listu, ktokolwiek nim jest, jest heretykiem i bez wątpienia jest nieprzyjacielem katolickiej prawdy" ${ }^{18}$.
\end{abstract}

Po takim sprytnym zabiegu przechodzi Maksencjusz do oskarżenia papieża, że zlekceważył doktrynę mnichów, którą oni, po pełnej przygód podróży, przedstawili w Rzymie:

„Mnichom proszącym o odpowiedź biskup Rzymu w ogóle nie odpowiedzial [...]. Stąd można wnosić, że [...] on bardziej wprowadza nieświadomych w błąd, skoro nie zdołał pytającym o radę wskazać właściwej drogi”.

Następnie oskarża papieskiego legata o nestorianizm i podaje po raz pierwszy formułę teopasyjną:

„Nie uwolnił także (papież) od błędu żadnym pouczeniem tych, których legat jego Dioskur spętał sidłami zdrady nestoriańskiej, zaprzeczającej, że Syn Boga jest jednym ze Świętej i niepodzielnej Trójcy"19.

contra eam non est ausa assurgere, ne mox validissimis eius iaculis prosternatur, ipsius adumbrata specie adversus eam dimicat".

18 Tamże, PG 86, 95B-96C: „Quapropter, quoniam quaedam fertur ab inimicis ubique Epistola, quasi a Romano episcopo destinata, in qua multa inaniter contra Scytharum monachos digesta reperiuntur , neccesario consideravi ipsius epistolae dictis respondere [...]. Unde securus iam hunc laborem, Deo me adiuvante, aggrediens, primo obsecro an eadem epistola a Pastore Ecclesiae, an sit potius ab inimicis videamus, composita. Ambigo enim quomodo illae sacerdotales litterae approbandae sint, quae nulla luce radiant veritatis, nec aliquam in se doctrinae continent rationem [...] rationis aut consequentiae reperiatur, sed tota criminationibus obtrectationibusque vanis (quae solent ex rancore adversantis procedere animi) videatur referat [...]. Si tamen non est (quod magis credendum aestimo) ab haereticis ficta, qui ad conturbandos fidelium animos, et ad commovendam memorato viro invidiam, ipsam sub eius nomine titulatam ubique proferunt, perpetuam volentes inter Ecclesias esse discordiam [...]. Nunc certe auctorem huius epistolae haereticum esse, quisquis ille est, et inimicum catholicae veritatis, non est dubium, quod mox ex ipsius dictis docebimus".

19 Tamże, PG 86, 95B-96B: „Quod monachis responsum quaerentibus, Romanus episcopus dare omnino distulerit [...]. Unde iuxta propriam definitionem, ipse ignorantes plenius impulisse convincitur in errorem, qui recti tramitis indicia nullatenus aequievit requirentibus demonstrare, eosque quos legatus suus Dioscorus Nestorianae perfidiae laqueis compedivit, Filium Dei unum negando esse ex sancta et individua Trinitate, nullo salubris doctrinae suffragio liberare". 
Po przedstawieniu swojej tezy, która w liście będzie wracać jak bumerang, Maksencjusz rozpoczyna analizę poszczególnych fragmentów listu Hormizdasa do Possesora. I tak, na zdanie papieża: „wyznaję $\mathrm{z}$ radością, iż $\mathrm{z}$ twego listu wynika żar wiary. Zapalony jej miłością ubolewasz nad ponownym ożywieniem przewrotności niewiernych w Konstantynopolu"20 Maksencjusz odpowiada:

„W tym mieście wszyscy ci, którzy są rzeczywiście wiernymi, nie zaprzeczą, że Possesor, do którego biskup Rzymu pisze w tej sprawie, nie tylko nie wyznaje, że Chrystus Syn Boga żywego jest jednym z niepodzielnej Trójcy, lecz sprzeciwia się tym, którzy to głoszą i oskarża ich o bezbożne zuchwalstwo i odszczepieństwo [...]. Przez to przewrotność nestoriańska może być głoszona przez jej zwolenników"21.

I dokłada papieżowi w zdaniu:

„Któż zatem wątpiłby, iż ten, który oświadcza w swoim liście, że z zadowoleniem znalazł $u$ adresata gorliwość wiary, należy do tych, którzy sprzeciwiają się bezbożnie świętej nauce" 22 .

\section{Zdaniem Maksencjusza papieżowi brak miłości bo pisze dalej:}

„nie należy wierzyć, że można spotkać płomień miłości u tych, którzy zaślepieni w swojej złości, uważają za upadłych i godnych pożalowania tych, którzy zbrojni w broń prawdy katolickiej, obalają wrogie argumenty heretyków"23.

Przytaczając następny passus $z$ listu papieża mówiący o tym, że Kościół trwa nieporuszony mimo burz, dlatego że kierowany jest ręką wprawnego Sterni$\mathrm{ka}^{24}$, umiejętnie wprowadza znaną już nam formułę, czyniąc $\mathrm{z}$ niej niejako gwarant prawdziwości Kościoła:

„Prawdziwy Kościół Boży, któremu nieobce są burze, to ten, który przepowiada Boga prawdziwego, a zatem jednego z Trójcy - Emmanuela. Ilekroć jest dręczony

${ }^{20}$ Epistola Hormisdae ad Possessorem 2, CSEL 35/2, 696-697 lub PG 86, 81B: „libenter in litteris tuis fidei tuae me fateor invenisse fervorem, cuius calore succensus redivivam in illis partibus infidelium perversitatem vigere suspiras".

21 Joannis Maxentii ad epistolam Hormisdae Responsio, PG 86, 96CD: „In hac urbe, forum duntaxat qui verte fideles sunt, ambigit nemo, Possessorem, ad quem et de quo haec iste scribit. non solum non confiteri Christum Filium Dei vivi unum ex individua Trinitate, sed et adversari eis qui hoc fiducialiter confitentur, atque infideles et perfidos nefanda accusare temeritate [...] et Nestoriana pravitas a suis fautoribus libere valeat praedicari".

22 Tamże, PG 86, 96D: „Quis ergo iam dubitet hunc, qui se huius fidei fervorem libenter in eius litteris invenisse testatur, unum ex eorum numero esse qui huic sanctae sententiae impie contradicunt?".

${ }^{23}$ Tamże, PG 86, 97A: „Nec apud eos charitatis igniculus inveniri posse credendus est, qui pravitatis suae malitia excaecati, lapsos et lamentabiles indicant eos qui armis catholicae veritatis instructi, haereticorum inimica destruunt argumenta".

${ }^{24}$ Por. Epistola Hormisdae 3, por. wyzej nota 14. 
różnymi wrogimi falami, trwa niewzruszony, bo jest kierowany sterem prawdziwego Boga"25.

A dalej atakuje papieża:

„Ci, którzy bluźnierczymi ustami zaprzeczają naturze Boga, odstępują od katolickiej prawdy, a stawszy się odszczepieńcami, walczą bronią własnej bezbożności przeciwko Kościołowi, który ich zrodził"26.

Po raz kolejny oskarża papieża o brak zainteresowania doktryną mnichów, gdy przytaczając jego słowa o staniu na mocnych śladach, by nie ulec obcym błędom i zamieszaniu panującemu w świecie powiada:

„Ponieważ nie wątpisz, że owo zamieszanie istnieje wszędzie na świecie, to dlaczego nie wyjaśniasz, w jakiej dziedzinie należy stąpać w ślady tego, co pewne? Tego wymaga prawdziwość nauczania, aby ci, którzy cię słuchają nie popadli w błąd. A może to nastąpić, ponieważ chytrze próbujesz skrywać swoją przewrotność, lecz katolicka prawda pozbawia cię dostojności"27.

Następne zdanie przytoczone z listu papieża pozwala Maksencjuszowi oskarżyć go o pychę, w odpowiedzi na jego zdanie: „Przez cały prawie rok znosiliśmy przewrotność pewnych Scytów [...]. Znosiliśmy ich cierpliwie, spodziewając się, że łagodnością uleczymy ich od ran wewnętrznych, tolerując ich chytrość $w$ budowaniu krętactwa i sianie pełnych nienawiści zatrutych nauk pod pozorem pobożności"28. Na to odpowiada Maksencjusz:

,powyższymi wypowiedziami skierowanymi przeciwko mnichom [...] zapalony żagwiami gniewu i podniecony bodźcami nienawiści [...] obraża ich nierozumnie, siebie samego stawiając ponad poglądami wszystkich ludzi [...]. Wydaje się zatem, że autor tego listu tylko z pozoru jest katolikiem, a nie z czynu i prawdy. Działając bowiem przeciwko tak pobożnym mnichom przyczynia się do wyrabiania niesprawdzonych sądów o nich. Skoro jego wlasne słowa świadczą o nim jako nieprzyjacielu katolickiej prawdy, to któż nie zawaha się wyznać, że on podniecony heretyckim duchem podle te słowa wszystkie wypluł przeciwko tymże mnichom. I nie owi mnisi, którzy

25 Joannis Maxentii ad epistolam Hormisdae Responsio, PG 86, 97B: „Vera Dei Ecclesia , cui non sunt haereticorum ignotae procellae, non est illa quae Christum gratia, non natura Deum confitetur, sed illa quae Deum verum, et ob hoc unum ex Trinitate praedicat Emmanuel. Propterea denique variis incusantium fluctuum laborat quidem vexata turbinibus, sed nullo pacto subruitur. Manet namque semper immobilis, quia a veri Dei regitur gubernaculo".

26 Tamże, PG 86, 97D: „qui ore sacrilego, natura Deum negantes, a catholica veritate desciscunt, et apostata effecti, armis propriae impietatis adversus eam, quae eos genuit, dimicant?".

${ }_{27}$ Tamże, PG 86, 98A: „Cum ubique terrarum permistionem istam esse non ambigas, cur in qua parte fixis deceat stare vestigiis, omnino non explicas? Praesentim cum hoc doctrinae exigat ratio, ne minus instructi qui te audiunt alienis involvantur erroribus, nisi quia callide tuam niteris occultare perfidiam? Se te splendore suo detegit catholica veritas".

28 Epistola Hormisdae ad Possessorem episcopum 6, CSEL 35/2, 697: „Quales per hunc fere iugem annum quorundam Scytharum [...] subtili tectas calliditate quasdam versutias et sub religionis obtentu famulantia odiis suis venena pertulimus studentes eos ab interno vulnere medicabilis patientiae moderamine sanare". 
postępując za katolickimi dogmatami wyznają, że Chrystus Syn Boga jest jednym ze świętej i jednej istoty Trójcy, lecz ten, który bezbożnie temu zaprzecza, jawnie naraża się na zarzut, że wymyśla misternie jakieś przewrotności niepokojąc umysły wiernych. Pod pozorem religii chce rozsiewać po całym ciele Kościoła nie tylko rzeczy służące nienawiści, lecz także trucizny swego błędu. Co więcej, dowodzi, że twierdzenia mnichów są grotami kuszenia dla niego samego"29.

I tu następuje niejako mocne forte kilkakrotnie powtarzającej się formuły teopasyjnej, jak gdyby częstym jej przytaczaniem z mocą, Maksencjusz miał nadzieję przekonać do niej papieża:
„A może nieprawdą jest katolickie wyznanie, że Chrystus Syn Boga Żywego jest jednym ze świętej $\mathrm{i}$ jedynej Trójcy? Czy nie na potwierdzenie tej nauki mnisi wyruszyli do biskupa Rzymu, co wiadome jest wszystkim, nie tylko w tym królew- skim mieście, ale i w całej Italii? Także heretycy przytaczają na potwierdzenie swoich błędów ów list, na jaki odpowiadamy. Często u tych mnichów wywołuje nienawiść fakt, iż wszyscy powodowani dostojeństwem biskupa Rzymu mają jako- by zakaz wyznawania, że Chrystus Syn Boga jest jednym z Trójcy. Któż jednak nie wyznaje tej katolickiej nauki, którą czci i glosi Kościół Boży? Dlaczego więc, tenże obecnie sprawujący urząd biskup rzymski poprzez swój list i gloszone slowa za- kazuje wyznawać, że Chrystus Syn Boga to jeden ze świętej i niepodzielnej Trójcy? Kościół katolicki, który nigdy nie przestał czcić biskupa katolickiego, umie też rozpoznać i potępić heretyków, których tezom nigdy nie będzie poshuszny" ${ }^{30}$.

\section{W następnym zdaniu wyłuszcza Maksencjusz, jak też rozumie swoją formułę:}

„Zatem kazdy, kto nie wyznawałby, że Chrystus Syn Boga żywego jest jednym z Trójcy, ten oślepiony ciemnościami przewrotności nestoriańskiej skłania się do

29 Joannis Maxentii ad epistolam Hormisdae Responsio, PG 86, 98D-99C: „His denique ita praemissis, specialiter iam contra eos, pro quibus agimus, monachos iracundiae facibus accensus, et invidiae stimulis incitatus, totus intendit [...] falsique criminationibus nititur obfuscare, seipsum tetri erroris nigredine adopertum, cunctorum aspectibus anteponit [...]. Quapropter si professione saltem, aut specie esset iste catholicus, qui specie et professione tantum (non opere et veritate) religiosos eos contra quos, agit, audet dicere monachos, credi forsitan poterat recto de eis et vero exaggerare iudicio. At vero ubi inimicum eum catholicae veritatis sua ipsius dicta redarguunt, quis ambigat haeretico eum spiritu exagitatum inique haec omnia adversus eosdem monachos evomuisse? Neque enim illi qui catholica sequentes dogmata, Christum Filium Dei unum confitentur esse ex sancta et unius essentiae Trinitate, sed iste potius qui hoc impie denegat, subtili tectas calliditate quasdam versutias machinari, ac fidelium animos inquietare, et sub obtentu religionis famulantia corpus Ecclesiae velle diffundere manifestissime confutatur. Praesertim qui hanc sanctam et catholicam vocem tentationis sibimet aculeum esse testatur".

${ }^{30}$ Tamże, PG 86, 99C: „An forte non est catholicum, Christum Filium Dei vivi unum confiteri ex sancta et individua Trinitate? Pro hac etenim sola sententia Scytharum monachos constat ad Romanum fuisse profectos episcopum, sicut omnibus pene, non solum in hac regia urbe, verum etiam in universa Italia Catholicis notum est. Nam et ipsi haeretici (ut superium dictum est) ad hoc ubique hanc ipsam, cui respondimus, Epistolam proferunt, quatenus et saepedictis monachis invidiam concitent, et omnes quasi ex auctoritate eiusdem Romani episcopi prohibeantur Christum Filium Dei unum confiteri ex Trinitate. 
stwierdzenia, iż On, który za nas podjąl krzyż, istnieje jako czwarta i zewnętrzna w stosunku do Trójcy osoba"31.

Następnie posuwa się Maksencjusz do stwierdzenia, że papież w głębi duszy popiera formułę teopasyjną, o czym świadczyć ma jego poufny list, rzekomo wysłany przez nieznanego znakomitego Rzymianina, pełniącego funkcję magister militum. W tym to rzekomym liście papież miał napisać o swoim legacie Dioskurze: „gdyby Dioskur nie wyznał, że Chrystus Syn Boga, który w ciele został umęczony, jest jednym ze świętej i niepodzielnej Trójcy, ma być utopiony w morzu"32. Takim argumentem chciał Maksencjusz pokazać, że atakowany przez niego list, jeśli nie był jakimś schizofrenicznym wytworem Hormizdasa, skoro pisał w nim coś zupełnie innego niż w poufnym rzekomym liście, o którym nic nie wiemy, to tylko dlatego, ze papież został omamiony przez Dioskura. Tak czy inaczej, jest heretykiem, bo ,jako spór o słowa i spowodowanie zamętu u wiernych traktuje wyznanie, że Chrystus Syn Boga żywego jest jednym z Trójcy"33.

Polemika $\mathrm{z}$ następnym passusem $\mathrm{z}$ listu papieża, mówiącym o zniszczeniu zarazy błędu i o uspokojeniu się mnichów, jak przystoi tym, co poshuszeństwo winni mieć za cnotę ${ }^{34}$, wydobywa na jaw zarozumiałość Maksencjusza, który uważa, że tylko nauka mnichów jest zdrowa a papieska nieprawdziwa:
„Nie ma wątpliwości, że jak dogmaty katolickie są zbawienne dla wiernych, tak niosą śmiertelne zagrożenie dla niewiernych [...]. Zdaje sobie sprawę [papież], że jego przewrotna myśl jest niszczycielska, a ta, którą głoszą mnisi scytyjscy jest strzeżona łaską Bożą. Ich myśl zatem nigdy nie zostanie wyrwana, gdyż jej ożywcza słodycz karmi serca wiernych. Dlatego [papież] nigdy nie zazna spokoju płynącego ze słodyczy tej łaski, ponieważ - jak sam twierdzi - nigdy serca łatwo ulegające złu nie będą posłuszne postanowieniem prawdy, nigdy pycha zadufana w swoich są- dach nie przywdzieje pokory posłuszeństwa. Stąd nie tych, którzy unikają pokoju $z$ heretykami, lecz raczej właśnie jego należy uznać za pobudzającego do sprzeczek, bezbożnie opierającego się prawdzie, nie zgadzającego się na katolicki pokój" ${ }^{35}$.

${ }^{31}$ Tamże, PG 86, 99D-100A : „Quia quisquis hoc non confitetur, non est dubium quod Nestorianae perfidiae tenebris excaecatus, quartum et extraneum a sancta et inneffabili Trinitate, eum qui pro nobis crucem sustinuit, praedicare contendat".

32 Por. tamże, PG 86, 100AB: „Qui etiam ut se a pravitate proprii legati purificaret, multis idoneis viris praesentibus, Romanum virum gloriosissimum magistrum militum deprecatus est, quatenus sum verba piissimo imperatori insinuaret quae fuere huiusmodi : «Nisi Christum Flium Dei, qui pro nobis passus est in carne, unum esse ex sancta et individua Trinitate fuerit confessus Dioscorus, pelago demergatur»".

${ }^{33}$ Tamże, PG 86, 100B: „Verumtamen, sive ab hoc, sive a quolibet alio haec sit scripta Epistola, non est dubium auctorem eius esse haereticum, qui contentionem verborum et subversionem audientium, iudicat Christum Filium Dei vivi unum fateri ex Trinitate".

${ }^{34}$ Por. Epistola Hormisdae ad Possessorem 7, CSEL 35/2, 698.

35 Joannis Maxentii ad epistolam Hormisdae Responsio, PG 86, 101AB: „Non est dubium catholica dogmata, sicut fidelibus salutifera ita esse mortifera infidelibus [...]. Nec immerito ; videt 
Maksencjusz okazuje się tu mistrzem polemiki: zarzuty papieża wobec mnichów skierować przeciw niemu, a to już jest sztuka. A oto dalszy tok jego rozumowania:
„Autor listu [papież] wzburzony trucizną nienawiści dowodzi, że u mnichów scy- tyjskich brak milości zgodnej z nowym Przykazaniem. Dlatego nie spogląda na nich jako na tych, którzy za łaską Bożą skłaniają się ku wiernym, lecz ku związkom $\mathrm{z}$ niewiernymi. Oskarża ich bezwstydnie o to, że chcą kierować się tylko swoim rozumem, dbając nieustępliwie o własne zdanie, choć prawda swoimi argumenta- mi świadczy, że oni są w pełni posłuszni" ${ }^{36}$.

Później następuje polemika, którą pominiemy, bo posługuje się w niej Maksencjusz niuansami słownymi tak dalece drobiazgowymi, że łatwo stracić wątek. Chodzi o polemikę: czy Chrystus jest jedną osobą z Trójcy czy też jednym z Trójcy (una persona ex Trinitate, non autem unum ex Trinitate). Dla Maksencjusza jest to istotne, bo według niego, gdyby Chrystus był jedną osobą z Trójcy, to byłby tylko zastępcą (wikariuszem) Słowa Bożego, a nie Bogiem-Słowem. Powróćmy do analizy papieskiego listu przez Maksencjusza. Na zarzut papieża, że „mnisi chciwi nowinek gardzą dawnymi autorytetami, a uważają za prawdziwą jakąkolwiek wymyśloną sentencję "37 odpowiada:
„O bezwstydna i ghupia lekkomyślności heretyków [...]. O nieszczęsna perfidio! Mnisi nie uważają, lecz wierzą w to, że słuszną jest droga wiedzy. Oni wyznają, że Chrystus Bóg-Słowo jest jednym z Trójcy. Przeto nie za wzgardzicieli winni być uznani, lecz za czcicieli dawnych autorytetów. Oni świętej nauki lekkomyślnie nie przyjęli, jak ty szydzisz [...], lecz wyznaja ją wiernie według tradycji boskich przy- kazań i świętych Ojców. I dlatego nie mnisi, lecz raczej ty jawisz się jako żądny nowinek, bowiem usiłujesz twierdzić o Bogu Chrystusie, że jest czwartym i odręb- nym od świętej niepodzielnej Trójcy, czego nikt prócz Nestoriusza i jego zwolen- ników nie odważył się głosić w Kościele [...]. Któż nie zauważy w następnych

\footnotetext{
namque propriae perfidiae hanc esse sententiam sine dubio peremptoriam, quae illorum visceribus, quos divina custodit gratia, ideo nunquam evellitur, quia eius vitalis suavitudo nutrit et fovet corda fidelium. Hic autem idcirco nullatenus huius gratiae suavitudini acquiescit, quia, sicut ipse ait, nunquam male sibi credula corda veritatis obtemperant institutis, nunquam induit obedientiae humilitatem opinionibus suis vallata superbia. Unde non iam illi qui haereticam pacem refugiunt, sed iste potius contentionum stimulis assuetus penitus comprobatur, qui veritati impie resistens, a catholica pace dissencit".

36 Tamże, PG 86, 101BC: „Adhuc odii sui veneno turbatus, nunquam charitatem novo praecepto commendatam, nunquam pacem Dominico discessu relictam apud Scytharum monachos esse, conqueritur: quia eos prospicit pro zelo catholicae fidei non fidelium, sed infidelium vigilanter per Dei gratiam declinare consortia. Eosdem una pertinacis propositi cura deditos rationi velle imperare, non cedere impudenter accusat, eum eos veritas suis penitus approbat rationibus subjectos".

37 Epistola Hormisdae ad Possessorem 7, CSEL 35/2, 698: „Contemptores auctoritatum veterum, novarum cupidi quaestionum; solam putantes scientiae rectam viam qualibet conceptam facilitate sententiam".
} 
zdaniach, że popełniwszy wielką głupotę obrażasz tak pokornych wyznawców, jakimi są mnisi. Twierdzisz bowiem, że oni są «nauczeni rozsiewać przestępstwa przygotowywać truciznę zawiści i nienawiści do jedności ciała Kościoła, organizować bunty [...], a zamiast posłuszeństwa [...] zwykli kochać krnąbrność pychy» ${ }^{38}$. Tak można twierdzić - zgodnie z prawdą - jedynie o nauce tych wszystkich, którzy oślepieni ciemnościami niegodnego błędu, sprzeciwiają się katolickiej prawdzie. Taż właśnie prawda piętnuje ciebie jako przestępcę i kłótliwego zazdrośnika oraz nienawistnego miłośnika upartej pychy i nieposłuszeństwa. Nie ma wątpliwości, ze to ty jesteś nieprzyjacielem Kościoła, jak powyżej często dowodziliśmy" "39.

Dalej dostaje się czytelnikowi, a w jakimś sensie i nam, gdybyśmy mieli jeszcze inne zdanie, niż Maksencjusz po tak „druzgocącej” krytyce heretyków:

„Któż więc byłby tak ghupi i tępy, któryby nie sądził o autorze listu [papieżu], że jest hardym pyszałkiem i uparciuchem, o którym wie, że tkwi zawzięcie we własnym błędzie i nie chce ustąpić dogmatom katolickim. Albo któż nie udowodni, na podstawie pewnego i prawdziwego osądu, ze biskup Rzymu organizuje bunty i wzbudza nienawiść? Kto nie dojrzy, że rozsadza go podłe kłamstwo wymierzone przeciw katolikom? Czyż nie należy sądzić o podobnych mu wienawiści do nienaruszonego ciała Kościoła, że usiłują rozlać truciznę swej perfidii w jego członkach i odciągnąć od prawdziwego zbawiennego wyznania? Nie ma wątpliwości co do tego, że ty i tobie podobni usiłujecie dokonać tego, kiedy odwracając się plecami od prawdy rozgłaszacie, ze Chrystus Syn Boga nie jest jednym z Trójcy"40.

\section{${ }^{38}$ Tamże.}

39 Joannis Maxentii ad epistolam Hormisdae Responsio, PG 86, 102C-103B: „O impudens et stulta haereticorum temeritas, [...] o infelix perfidia! Sed omnino rectam credunt esse sententiae viam, qui Christum Deum Verbum, et ob hoc unum fatentur ex Trinitate. Nec contemptores, sed potius veneratores auctoritatum veterum comprobantur qui hanc sanctam et totius Ecclesiae sententiam, non, sicut tu temere insultas, qualibet facilitate susceptam, sed iuxta divinorum Eloquiorum et sanctorum Patrum traditionem fideliter confitentur. Et ideo non illi, sed tu potius novarum cupidus quaestionum detegeris, qui Deum Christum quartum et alienum a sancta et individua Trinitate conaris asserere, quod nullus unquam, praeter Nestorium sociosque eius, praedicare in Ecclesia usurpavit [...]. Iam vero in consequentibus quis non videat quanta eos repletus dementia laceres? «Docti, inquis, crimina serere, obtrectationum venena componere, integrum Ecclesiae corpus odisse, seditiones struere, invidiam concitare, et pro obedientia [...] obstinationem pertinacis amare superbiae». Cum haec non nisi de illis vero et certo omnium asseverentur iudicio, qui tenebris nefandi erroris caecati catholicae veritati resistunt, quapropter te potius criminatorem et obtrectatorem, seditiosum quoque et invidum atque amatorem pertinacis superbiae et inobedientem, non humanus error, sed ipsa veritas prodit, eius te inimicum esse non dubium est, sicut superius saepe probavimus".

${ }^{40}$ Tamże, PG 86, 103CD: „Quis autem tam stultus et hebes sit, qui non eum inobedientem, superbum et pertinacem iudicet, quem videt in proprio errore obstinate persistere, et catholicis nolle dogmatibus cedere? Aut quis non eum potius certo et vero iudicio seditionnes struere, et invidiam concitare arguat, quem perspicit adversus Catholicos iniqua dilatare mendacia? Quomodo autem non integrum Ecclesiae corpus odisse illi potius iudicandi sunt, qui perfidiae suae venena in eius membra conantur diffundere, eaque a propria et salutifera professione avertere? Quod te et omnes qui tibi consentiunt implere velle non dubitum est, qui callida tergiversatione Christum Filium unum non esse ex Trinitate praedicare contenditis". 
Oskarżając dalej papieża o bezczelność zawartą jakoby w jego słowach: „nie mogliśmy ich [mnichów] utemperować ani upomnieniami, ani łagodnością, ani autorytetem"41 pyta:

„od jakiego błędu, od jakiej pychy nie mogłeś ich odwieść swoimi upomnieniami, łagodnością i autorytetem? Pomijasz to chytrze, abyś czyniąc to, nie zdradzil siebie samego jako profana [...]. Winieneś mnichów pochwalić, a nie zganić występując przeciw nim kierowany swymi przekonaniami. Czyż nie potwierdzasz własnymi wypowiedziami, że nie pochwalając ich, na swoje zawstydzenie to uczyniłeś? Tak należy o tobie mniemać, skoro ani perswazją, ani lagodnością, ani powagą nie mogłeś przekonać mnichów do swej nieprawości”“42.

Następnie oskarża papieża, że przeinaczył zdarzenia, jakie zaszły w czasie pobytu Scytów w Rzymie:

„Teraz już należy rozważyć następujące słowa, które wszystkie są kłamliwe, bo podają w odwrotnym sensie to, co w Rzymie uczynione zostało przeciw samym mnichom" 43 .

I przytacza kolejny fragment $\mathrm{z}$ jego listu o działaniach mnichów pośród wiernych Wiecznego Miasta, którzy - jak twierdził papiez - przeciwstawili się ich $\operatorname{agitacji}^{44}$. Tu już Maksencjusz popuścił cugle swojej twórczej weny:

„O dziwna ślepoto szalonych i przeniewiercze kłamstwo umysłów wyzbytych prawdy! Nie godzi się tak otwarcie kłamać biskupowi rzymskiemu. Dobrze wiadomym jest wszystkim mieszkającym w Rzymie [...], że ludzką pokusą podniecony biskup Rzymu [...], skoro dowiedział się, że wraca Dioskur - chcąc wyświadczyć mu to dobrodziejstwo, by nie został publicznie oskarżony przez tychże mnichów o herezję - odprawiwszy obrońców, z wielkim pośpiechem skłonil ich do naglego opuszczenia Rzymu, chociaż nieraz, tak na naradzie kościelnej, jak również na zebraniu senatorów obiecywal, że w razie przybycia Dioskura da im postuchanie. Gdy mnisi byli przynaglani przez obrońców do opuszczenia Miasta, postanowili ukazać się w miejscach publicznych w tym celu, aby lud zaświadczył [...], że nie

41 Epistola Hormisdae ad Possessorem 9, CSEL 35/2, 698: „Non illos potuimus monitis, non mansuetudine, non auctoritate comprimere".

42 Joannis Maxentii ad epistolam Hormisdae Responsio, PG 86, 104A: „Sed a quo errore, a qua insolentia vestris monitis, vestraque mansuetudine vel auctoritate minime eos comprimere potueris, nullatenus exprimis. Quod ideo callide praetermittis, ne hoc faciens, temetipsum profanum et impium detegas [...]. Numquam etenim reor, quamvis laudandi fideles cupidus, ad eorum praeconia constantius haec dicere potuisses, quae nunc quasi in vituperationem monachorum, contra quos agere videris, conscripsisse te credis".

43 Tamże, PG 86, 104B: „Nunc iam sequentia consideranda sunt ubi perverso ordine ea quae Romae contra ipsos acta sunt monachos dirigens, cuncta mentitus es".

44 Por. Epistola Hormisdae ad Possessorem 9, CSEL 35/2, 698: "In publicum uaque prodiere conventum ad concussionem quietis circa regum etiam statuas inclamantes, et nisi fidelis populi constantia restitisset per diabolicae semina nefanda zizaniae apud illos dissensionem et discordiam commovissent, per quos adiutorio Dei de regionibus eorum est pulsa dissensio". 
oddalili się potajemnie [...]. Nie mogliby tego zrobić, gdyby nie dał im tej możliwości rzymski lud, który nie podniósł wprawdzie w ich obronie glosu, to jednak swym szemraniem wobec obrońców, którzy przynaglali ich do odejścia stamtąd, sprawil, że stało się ono wiadome powszechnemu Kościolowi. A zatem nie lud, jak kłamliwie się twierdzi, lecz obrońcy skłonili mnichów do opuszczenia Rzymu [...]. Dlaczego więc biskup Rzymu twierdzi, że stałość ludu przeciwstawiła się im? Przecież lud wiedział, że oni wyszli do niego ze względu na wyrządzony im gwałt [...]. Jeżeli zaś rozważyłbyś pilnie słowa z listu [papieża], to doszedłbyś do wniosku, że biskup Rzymu oskarża ów lud o gwałt i herezję, mimo ze kiedy indziej mówi o nim, że odznacza się wierną stałością"45.

Nawet w trakcie przedstawiania swojej wersji wydarzeń nie zapomniał Maksencjusz o propagowaniu formuły teopasyjnej, bo pisze kontynuując wątek wydarzeniowy:

„Jeśli owej nauce gloszonej przez mnichow, która zachowywana jest i broniona przez Kościół katolicki oparł się lud rzymski (nauce, w której Chrystus Syn Boga jak głosi wiara - jest jednym ze świętej i niewysłowionej Trójcy), to już nie tylko on sam, zaślepiony ciemnościami błędu twierdzi, że ta nauka jest nasieniem - przepraszam za słowo - diabelskiego posiewu, ale dowodzi, że cały lud rzymski jest (oby nigdy to nie nastąpiło) heretycki. Gdyby zaś aż do pojawienia się przeciwnika [Dioskura] lud sprzeciwial się tymże mnichom, chcącym pozostać w Rzymie, aby w obecności tegoż [Dioskura] spór zakończył się sprawiedliwie, to zaiste głupi i nikczemny byłby ten lud, który odmówiłby posłuchania, mimo iż zgodnie z prawem o nie prosili i wypędził ich gwałtem ze swych okolic. Stąd niech uważają i wstydzą się ci, którzy rozgłaszają takie opinie" ${ }^{\text {46 }}$.

45 Joannis Maxentii ad epistolam Hormisdae Responsio, PG 86, 104B-105B: „O mira furiosorum caecitas, et a veritate alienatarum mentium criminosa fallacia! Neque enim fas est tam aperte posse mentiri Romae episcopum [...]. Humana namque tentatione praeventus idem Romanus episcopus [...] postquam comperit reverti Dioscorum, volens ei praestare hoc beneficium, ne in publico ab eisdem monachis argueretur haereticus, missis defensoribus cum ingenti violentia eos ab urbe Roma subito exire compulit, quanquam saepius publice et privatim, tam in conventu ecclesiastico quam etiam omnium senatorum, eis veniente Dioscoro audientiam dare esset pollicitus. Qui cum ab ipsis defensoribus egredi urgerentur, compulsi sunt in locis publicis populum contestari, ne post suum discessum clame os recessisse fautores Dioscori apud Ecclesiam diffamarent, unde factum est ut salutem eis parva dilatio praestaretur, quandiu se exinde egredi praepararent, sub quo tempore scriptis, omnia quae in se gesta sunt facultas data est contestandi. Quod tamen nunquam facere potuissent, nisi hoc eis Romanus populus praestisset, qui, licet pro eis minime proclamaret, ipsa tamen sua tacita murmuratione defensores, fecit ut eorum violenta expulsio universae Ecclesiae innotesceret. Non ergo (ut iste mentitur) populus, sed defensores Ecclesiae, eos exinde egredi compulerunt [...]. Cur ergo eis fidelis populi constantia, ut iste dicit, resisteret, quos videbat pro sibi ingesta violentia progressos ad publicum? [...]. Verum si diligentius haec istius verba consideres, invenies eum etiam Romanum populum quem fidelem asserit, non solum ut violentum, verumetiam, ut haereticum accusare".

46 Tamże, PG 86, 105BC: „Nam si de illa sententia, quam universa Dei tenet et defendit Ecclesia, monachis in publico disputantibus, hoc est, qua Christus Filius Dei unus esse creditur ex sancta et ineffabili Trinitate, Romanus populus resistit; iam non tantum iste, qui erroris sui tenebris excaecatus, diabolicae semina nefanda zizaniae hanc sanctam sententiam asserit, verume- 
Na koniec Maksencjusz jeszcze raz zaatakowal papieża, gdy ten w swym liście ostrzegał Possesora przed oszustwem mnichów, co do wydarzeń w Rzymie $^{47}$, i pisał:

„Kto pragnie dowiedzieć się prawdy, ten raczej da wiarę zeznaniom mnichów, których doświadczono w tymże mieście w miejscach publicznych, nie zaś pismu biskupa Rzymu, który jest uważany nie tylko za ich wroga, lecz za wroga całego Kościoła. Do takiego stopnia jest jego przeciwnikiem, pozując na obrońcę, że uważa prawdomównych mnichów za nieprzyjaciół tegoż Kościoła. Jeśli rzeczywiście owi mnisi chcieliby niecnie przeciwko temuż Kościolowi w Rzymie coś zmyślić, to nie uwierzę nigdy, żeby w ten sposób zdobyli się na porzucenie wiary tegoż Kościoła, jak właśnie biskup rzymski, który ich haniebnie z ciała Kościoła wyrzuca i rani”"48.

I raz jeszcze nie omieszkał Maksencjusz powtórzyć:

„Zgodnie z boskimi słowami i tradycją świętych Ojców mnisi wyznają, że Chrystus Syn Boga, co do istoty jest w dwóch naturach, czyli według połączenia składu jedności i odrę̧bności, o czym naucza wiara katolicka. Zatem mnichom ta jego fałszywość nie tylko niczego nie odbiera, ale nawet przynosi wielką nadzieję szczęśliwości według słów Pana: «Blogosławieni jesteście, gdy ludzie wam złorzeczą i będą was prześladować i kłamiąc mówić będą wszelkie złe słowo przeciwko wam ze względu na mnie» (Mt 5, 11),49.

Po tym umieszczeniu mnichów w niebie pozostaje Maksencjuszowi tylko jedno: wrzucić papieża do piekła, co też uczynił słowami:

„Sobie zaś bez wątpienia gotuje on wieczną śmierć, ponieważ fałszywy świadek nie pozostanie bez kary"

tiam omnis antedictus populus haereticus (quod absit!) esse convincitur. Si autem usque ad aemuli sui praesentiam eisdem monachis ibidem remorari volentibus, quo ipso praesente causa eorum aequo ordine terminaretur, populus restitit, stultus, et iniquus erat idem populus, qui audientiam iure petentibus denegavit eosque a suis violenter repulit regionibus. Huc attendat et confundantur hi qui exinde eos fuisse iactitant".

47 Por. Epistola Hormisdae ad Possessorem 9-10, CSEL 35/2, 698-699.

48 Joannis Maxentii ad epistolam Hormisdae Responsio, PG 86, 106B: „Qui vere scire desiderat, ex eorum contestationibus quas in eadem urbe locis publicis defixerunt, magis agnoscet, quam ex istius scriptis, qui non est eorum tantum, sed et totius Ecclesiae inimicus agnoscitur. Nam et ipsius Romanae Ecclesiae, cuius se quasi defensorem simulat, in tantum adversarius denotatur, ut si memorati monachi, quos quasi eidem Ecclesiae contrarios aestimat, inique adversus eam in his partibus aliqua fingere voluissent, nunquam credo ita eiusdem Ecclesiae fidem derogare praevaluissent, quemadmodum iste, qui ex persona ipsius Ecclesiae ideo inique eos obtrectat et lacerat".

${ }^{49}$ Tamże, PG 86, 106BC: „quia iuxta divina eloquia, et sanctorum Patrum traditiones Christum Filium Dei, quem in duabus naturis essentialiter, sive iuxta compositionem unitionis et inconfusionis docet fides catholica, confitentur, et illis quidem huius falsitas, non solum auderet nihil, verum etiam multam spem beatitudinis confert, Domino dicente: «Beati estis cum vos exprobraverint homines, et persecuti fuerint, et dixerint omne verbum malum adversus vos mentientes propter me» (Mt 5, 11)".

${ }^{50}$ Tamże, PG 86, 106C: ,[...] sibi autem perpetuam sine dubio contulit mortem «quia falsus testis non erit impunitus" ( $\operatorname{Prz} 19,5)$ ". 
Tak oto wygląda ów paszkwil mnicha Maksencjusza. Jak zakończyła się cała sprawa? Maksencjuszowi włos z głowy nie spadł, bo nie mógł spaść, choćby dlatego, że formę inwektywy każdy rozumiał, a poza tym szanowano wolność wypowiedzi może bardziej niż dzisiaj. Nie wiemy, czy papież przyjął do wiadomości replikę Maksencjusza, nie znamy bowiem na nią żadnej odpowiedzi. Wiemy natomiast, że 25 marca 521 r. skierował do Bizancjum dwa listy do cesarza Justyna $^{51}$ oraz jeden do nowego patriarchy Konstantynopola Epifaniu$\mathrm{sza}^{52}$. W tych to listach, obok wielu innych spraw, dał umotywowaną opinię na temat teopasyjnej kontrowersji. Poddał więc osądowi formułę mnichów scytyjskich i uczynił to w kontekście nauki o Trójcy Świętej. W rezultacie zakazał głoszenia czegoś więcej, niż to było zawarte w nauczaniu Leona Wielkiego i Soboru Chalcedońskiego. Według niego formuły tam podane całkowicie wystarczały ${ }^{53}$. W taki to sposób rozstrzygnął papiez, przynajmniej na jakiś czas, problem zaakceptowania formuły teopasyjnej. Nie odrzucił jej, uniknął też jej aprobaty, a jedność w Kościele zachowal ${ }^{54}$.

\title{
JOANNIS MAXENTII LIBELLUS FAMOSUS UT EXEMPLUM INVECTIVAE CHRISTIANAE
}

\author{
(Argumentum)
}

Hac in brevi dissertatiuncula auctor epistolam Joannis Maxentii monachi, quae responsio ad epistolam Hormisdae papae (514-523) habetur, uti exemplum invectivae christianae tractat atque late scrutatur.

51 Por. Epistolae Hormisdae ad Iustinum Augustum (Collectio Avellana 236 i 238), CSEL 35/2, 716-722 i 734-738.

52 Por. Epistola Hormisdae ad Epiphanium Constantinopolitanum (Collectio Avellana 237), CSEL 35/2, 722-733.

53 Por. Epistola Hormisdae ad Iustinum Augustum 6 (Collectio Avellana 236), CSEL 35/2, 718: "quid ergo est post illum fontem fidelium statutorum quod amplius, si tamen fidei terminos servat quamlibet curiosus scrutator inquirat ? Non opus aut adiectione plenis aut institutione perfectis, nisi forte mavult quisquam dubitare quam credere, certare quam nosse, sequi dubia quam servare decreta"; Epistola Hormisdae ad Epiphanium Constantinopolitanum (Collectio Avellana 237), CSEL 35/2, 730: „Haec si quemadmodum a patribus constituta sunt servant, credant nec definita transcendant ; a quo tramite qui declinant, ipsi nebulam dubitationis offundunt. Nobis autem illud apostolicum contentionis respondere necesse est : nos hanc consuetudinem non habemus nec ecclesia Dei".

54 Por. Haacke, dz. cyt., s. 90; E. Caspar, Geschichte des Papsttums von den Anfängen bis zur Höhe der Weltherrschaft, II, Tübingen 1933, 177. 